\title{
21st century citation analysis of the field of contact lenses
}

DOI:

10.1080/08164622.2021.1880867

\section{Document Version}

Accepted author manuscript

Link to publication record in Manchester Research Explorer

\section{Citation for published version (APA):}

Efron, N., Morgan, P. B., Jones, L. W., \& Nichols, J. J. (2021). 21st century citation analysis of the field of contact lenses. Clinical and Experimental Optometry, 104(5), 634-638. https://doi.org/10.1080/08164622.2021.1880867

\section{Published in:}

Clinical and Experimental Optometry

\section{Citing this paper}

Please note that where the full-text provided on Manchester Research Explorer is the Author Accepted Manuscript or Proof version this may differ from the final Published version. If citing, it is advised that you check and use the publisher's definitive version.

\section{General rights}

Copyright and moral rights for the publications made accessible in the Research Explorer are retained by the authors and/or other copyright owners and it is a condition of accessing publications that users recognise and abide by the legal requirements associated with these rights.

\section{Takedown policy}

If you believe that this document breaches copyright please refer to the University of Manchester's Takedown Procedures [http://man.ac.uk/04Y6Bo] or contact uml.scholarlycommunications@manchester.ac.uk providing relevant details, so we can investigate your claim.

\section{OPEN ACCESS}




\section{1st century citation analysis of the field of contact lenses}

\begin{tabular}{|c|c|}
\hline Journal: & Clinical and Experimental Optometry \\
\hline Manuscript ID & CEOptom-20-557-VP.R1 \\
\hline Manuscript Type: & Original Research Paper \\
\hline $\begin{array}{r}\text { Date Submitted by the } \\
\text { Author: }\end{array}$ & $\mathrm{n} / \mathrm{a}$ \\
\hline Complete List of Authors: & $\begin{array}{l}\text { Efron AC, Nathan; Queensland University of Technology, Insitute of } \\
\text { Health and Biomedical Innovation } \\
\text { Morgan, Philip; The University of Manchester, Faculty of Life Sciences; } \\
\text { Jones, Lyndon; University of Waterloo, Optometry } \\
\text { Nichols, Jason; University of Alabama at Birmingham, Office of Industry } \\
\text { Engagement }\end{array}$ \\
\hline Keywords: & bibliometrics, 21st century, citations, contact lenses, publication metrics \\
\hline Abstract: & $\begin{array}{l}\text { Clinical relevance: The scientific foundations for clinical contact lens } \\
\text { practice are rooted in the ophthalmic literature. This analysis of contact } \\
\text { lens papers celebrates contemporary research achievements in the } \\
\text { contact lens field. } \\
\text { Background: This work aims to assemble contact lens-related publication } \\
\text { metrics so as to identify the most impactful papers published so far this } \\
\text { century, as well the top countries, authors, institutions and journals. } \\
\text { Methods: A search was undertaken of the titles of papers on the Scopus } \\
\text { database to identify contact lens-related articles published this century. } \\
\text { The ten most highly cited papers were determined from the total list of } \\
4,164 \text { papers found. Rank-order lists by count were assembled for the } \\
\text { 'top } 25^{\prime} \text { in each of four categories: authors, institutions, countries and } \\
\text { journals. A } 20-y e a r \text { subject-specific contact lens h-index (hCL-20-index) } \\
\text { was derived for each author, institution, country and journal to serve as } \\
\text { a measure of impact in the field. The top } 10 \text { constituents (of the top 25) } \\
\text { of each category were ranked by hCL-20-index and tabulated for } \\
\text { consideration. } \\
\text { Results: The most highly cited paper this century is entitled "Soft contact } \\
\text { lens polymers: An evolution", by Nicholson and Vogt. Lyndon Jones is } \\
\text { the most impactful author, with a hCL-20-index of } 32 \text {. The University of } \\
\text { New South Wales (Australia) produces the most impactful contact lens- } \\
\text { related papers, and the United States is the most highly-ranked country. } \\
\text { Optometry and Vision Science is the most impactful journal in the } \\
\text { contact lens field. } \\
\text { Conclusions: Contact lens materials and lens-associated keratitis are } \\
\text { topics of high interest in the contemporary contact lens literature, with } \\
\text { an emerging interest in orthokeratology for myopia control and glucose } \\
\text { monitoring. Impactful } 21 \text { st century authors, institutions, countries and } \\
\text { journals are identified. Optometry is revealed as the leading profession } \\
\text { in relation to the publication of impactful contact lens-related papers. }\end{array}$ \\
\hline
\end{tabular}


1

2

3

4

5

6

7

8

9

10

11

12

13

14

15

16

17

18

19

20

21

22

23

24

25

26

27

28

29

30

31

32

33

34

35

36

38

39

40

41

42

43

44

45

46

47

48

49

50

51

52

53

54

55

56

57

58

59

60

\section{SCHOLARONE ${ }^{\text {m }}$ \\ Manuscripts}


CEOptom-20-????

\section{RESEARCH}

21 st century bibliometric analysis of the contact lens field

Nathan Efron* AC DSc PhD BScOptom

Philip B Morgan ${ }^{\dagger} \mathrm{PhD}$ BSc(Hons) MCOptom

Lyndon W Jones $\ddagger$ DSc PhD BSc(Hons) FCOptom

Jason J Nichols ${ }^{\S}$ OD MPH PhD

*School of Optometry and Vision Science, Queensland University of Technology, Kelvin Grove, Queensland, Australia

$\dagger$ Eurolens Research, Division of Pharmacy and Optometry, The University of Manchester, Manchester, UK \$Centre for Ocular Research \& Education (CORE), School of Optometry and Vision Science, University of Waterloo, Waterloo, Ontario, Canada and Centre for Eye and Vision Research (CEVR), Hong Kong §School of Optometry, The University of Alabama at Birmingham, Birmingham, Alabama, USA

Submitted:

Revised:

Accepted:

\section{[Running head]}

Contact lens bibliometrics

Key words: bibliometric analysis, $21^{\text {st }}$ century, citations, contact lenses, publication metrics

\section{[Corresponding author]}

Nathan Efron

n.efron@qut.edu.au 


\section{[Abstract]}

Clinical relevance: The scientific foundations for clinical contact lens practice are rooted in the ophthalmic literature. This analysis of contact lens papers celebrates contemporary research achievements in the contact lens field.

Background: This work aims to assemble contact lens-related publication metrics so as to identify the most impactful papers published so far this century, as well the top countries, authors, institutions and journals.

Methods: A search was undertaken of the titles of papers on the Scopus database to identify contact lensrelated articles published this century. The ten most highly cited papers were determined from the total list of 4,164 papers found. Rank-order lists by count were assembled for the 'top 25 ' in each of four categories: authors, institutions, countries and journals. A 20-year subject-specific contact lens h-index $\left(\mathrm{h}_{\mathrm{CL}}-20\right.$-index) was derived for each author, institution, country and journal to serve as a measure of impact in the field. The top 10 constituents (of the top 25) of each category were ranked by $\mathrm{h}_{\mathrm{CL}}-20$-index and tabulated for consideration.

Results: The most highly cited paper this century is entitled "Soft contact lens polymers: An evolution", by Nicholson and Vogt. Lyndon Jones is the most impactful author, with a $\mathrm{h}_{\mathrm{CL}}$-20-index of 32 . The University of New South Wales (Australia) produces the most impactful contact lens-related papers, and the United States is the most highly-ranked country. Optometry and Vision Science is the most impactful journal in the contact lens field.

Conclusions: Contact lens materials and lens-associated keratitis are topics of high interest in the contemporary contact lens literature, with an emerging interest in orthokeratology for myopia control and glucose monitoring. Impactful $21^{\text {st }}$ century authors, institutions, countries and journals are identified. Optometry is revealed as the leading profession in relation to the publication of impactful contact lens-related papers. 


\section{[Introduction]}

In 2011, two of the authors of this paper (NE, JJN) conducted a citation analysis of the contact lens field, ${ }^{1}$ essentially surveying papers published over the previous 110 years. That analysis (which was published in 2012) provided fascinating insights from an essentially historical perspective; however, the contact lens field continues to evolve, with new lens materials and designs frequently being introduced, along with novel paradigms such as myopia control and the incorporation of micro-electronics into contact lenses. Furthermore, an earlier generation of prominent contact lens researchers is gradually making way for a new breed of academics, sometimes emerging from countries not traditionally associated with contact lens research.

Subsequent bibliometric analyses of the contact lens literature have been published following on from the original work of Efron et al. ${ }^{1}$ Cardona and Sanz ${ }^{2,3}$ assessed the metrics of contact lens papers published in a single year - 2011 - to gauge topics of interest at that time. Wood and Dutta ${ }^{4}$ used publication metrics to generally reflect upon developments in the contact lens field over the past 50 years. Alvarez-Peregrina et al ${ }^{5}$ examined the literature specifically relating to bifocal contact lenses, and Villar-Collar et $\mathrm{al}^{6}$ and Nichols et al ${ }^{7}$ have undertaken a bibliometric analyses of the field of orthokeratology.

The aim of this paper is to undertake a bibliometric analysis of the $21^{\text {st }}$ century contact lens literature, focusing in particular on the most highly cited papers; the most impactful authors and the institutions and countries where they work; and the most prominent journals publishing these articles.

\section{Methods}

The search protocol used here was similar to that used for the 2011 analysis of Efron et al, ${ }^{1}$ except that the present work was undertaken using the Scopus database (Elsevier). The search was restricted to all research and review articles published in English between January 1, 2001 and October 14, 2020. A search term was derived to ensure (a) high sensitivity, including a wide capture of articles with "contact lenses" as the primary theme, and (b) high specificity, so as to rule out irrelevant or peripherally related articles.

Multiple iterations of search terms were investigated, including a variety of fields, but the final strategy employed was to search TITLE only (rather than abstract, key words or 'all fields'), employing the following search term:

TITLE( $\{$ contact lens\} OR \{contact lenses\} OR \{orthokeratology\} AND NOT \{implantable contact lens\}) AND (PUBYEAR>2000) AND (LIMIT-TO(SRC,’j”)) AND (LIMIT-TO(DOCTYPE, “AR”) OR LIMITTO(DOCTYPE, “re”)) AND (EXCLUDE(PUBYEAR, 2021)) AND (LIMIT-TO,”English”) 
The search revealed 4,164 contact lens-related papers; of these, 13.6\% have not received any citations, and the rest have in total been cited 74,361 times. The top 10 most cited papers were determined by simple sorting within Scopus.

The 4,164 contact lens-related papers also served as the database from which a targeted analyses were conducted in respect of the following four additional categories: authors, institutions, countries and journals. The first step was to generate a list of the top 25 in each of these categories by paper count, e.g. for the category 'authors', the author who had published the most papers in the pool of 4,164 contact lens-related papers was listed first, and so on, down to 25 authors.

Quality was assessed using the concept of $h$-index ${ }^{1}$ - a single metric that combines productivity (number of papers) and impact (number of citations). This metric can be applied to any category; for example, the h-index of an author is defined as the maximum value of $h$, such that the author has published $h$ papers that have each been cited at least $\mathrm{h}$ times. To continue with the example of 'authors'- a 20-year subject-specific contact lens hindex (the " $\mathrm{h}_{\mathrm{CL}}-20$-index") was derived for each author, to serve as a measure of the impact that each author has had in the field.

The $\mathrm{h}_{\mathrm{CL}}$-20-index of a given author was determined by sorting the subset of contact lens-related publications for that author by rank order of citations (from highest to lowest) and working down the list, starting with the paper that had the highest number of citations, to determine the first paper with a paper rank number that was larger than its number of citations. The $\mathrm{h}_{\mathrm{CL}}-20$-index for that author was identified as the number of the entry above the identified paper. This was repeated for each of the 25 most prolific authors; the top 10 were then identified and ranked in order of $\mathrm{h}_{\mathrm{CL}}-20$-index, with tied ranks broken in favour of a higher number of published papers. The same approach was applied for the analysis of institutions, countries and journals.

\section{$\underline{\text { Results }}$}

The $\mathrm{h}_{\mathrm{CL}}-20$-index for all contact lens-related papers published this century was determined to be 100 .

The ten most highly cited papers ${ }^{8-17}$ are listed in Table 1 . Five of these papers were published in ophthalmic journals, two in materials science journals, and one each in a general medical, 'natural sciences' and engineering journal.

Table 2 lists the 10 most impactful authors, ranked by $\mathrm{h}_{\mathrm{CL}}-20$-index, along with the total count of contact lensrelated papers published since 2001, and the ranking of each author (by paper count) from the 2011 analysis of 
Efron et al. ${ }^{1}$ Lyndon Jones is the top-ranked author, with the next three authors each separated by one $\mathrm{h}_{\mathrm{CL}}-20$ index point from the previous author.

The top 10 institutions from which papers emanated are listed in Table 3, ranked by $\mathrm{h}_{\mathrm{CL}}-20$-index, along with the total paper count and the ranking of each institution from the 2011 analysis of Efron et al. ${ }^{1}$ The University of New South Wales is the leading institution, as it was in 2011.

Table 4 lists the top 10 countries, ranked by $\mathrm{h}_{\mathrm{CL}}-20$-index, along with the total paper count and ranking of each country from the 2011 analysis of Efron et al. ${ }^{1}$ The United States retains top ranking, followed by Australia, then the United Kingdom.

The reason that the total paper count for Australian institutions exceeds that for Australia as a nation is because individual authors often list multiple institutions, e.g. in Australia, some authors designate that they work at both the University of New South Wales and the Brien Holden Vision Institute. When tallying data, a singleauthor paper stating this dual affiliation would result in one count for each of those two Australian institutions (i.e. two counts for Australian institutions), but only one count for the nation of Australia.

The top 10 journals publishing contact lens articles in the 21 st century are listed in Table 5 , ranked by $\mathrm{h}_{\mathrm{CL}}-20$ index, as well as the total paper count, and the ranking of each journal from the 2011 analysis of Efron et al. ${ }^{1}$ Optometry and Vision Science is the top-ranked journal. However, an obvious trend in publications in journals that has emerged in the last five years is a marked drop in contact lens publications in Optometry and Vision Science, and a significant increase in Contact Lens and Anterior Eye. It will be interesting to monitor this trend as it relates to the impact of these journals in the field going forward.

\section{Discussion}

This analysis reveals the most impactful articles, authors, institutions, countries and journals in relation to the $21^{\text {st }}$ century contact lens literature. A number of significant changes are evident when comparing these contemporary rankings with the analysis published by Efron et $\mathrm{al}^{1}$ in 2011 , the latter being more of an historic 'all time' overview of the contact lens literature, dating back to the year 1900.

An advantage of undertaking this contemporary analysis, compared with the earlier historic analysis, ${ }^{1}$ is that the search findings and consequent comparisons within each analysis are not confounded by factors such as differences in the capacity of more senior academics to accrue superior publication metrics by virtue of having worked in the field for a longer time span, or certain journals to do the same as a result of having been in 
existence for a greater number of years. That is, the 20 -year survey period puts all parameters considered on a "level playing field".

It should be noted when comparing the present rankings of authors, institutions, countries and journals with the rankings derived by Efron et al in $2011,{ }^{1}$ that the present rankings relate to impact (i.e. ranking by $\mathrm{h}_{\mathrm{CL}}-20$ index) whereas the 2011 rankings related to productivity (i.e. ranking by paper count).

\section{Highly cited papers}

Analysis of the ten most highly cited papers ${ }^{8-17}$ listed in Table 1 necessarily favours papers published earlier in the survey window, which have had a greater opportunity to accrue more citations. The top-ranked paper traces the evolution of soft contact lens polymers from hydrogels, developed in the 1960s, to silicone hydrogels, ${ }^{8}$ which became available around the turn of the century. The high citation count of this paper can be attributed to the keen interest in this new technology, which now dominates the market, whereby $72 \%$ of all contact lenses fitted today are made from silicone hydrogel materials. ${ }^{18}$

It is interesting to observe how the top ranked $21^{\text {st }}$ century papers in Table 1 compare to those tabulated in $2011,{ }^{1}$ the latter perhaps relating more to contact lens practice in the $20^{\text {th }}$ century. Two papers listed in $2011^{1}$ concerned corneal oxygen availability and hypoxic complications during lens wear; papers dealing with such topics do not appear in the current listing because silicone hydrogels have largely obviated concerns about hypoxia. ${ }^{19}$ Similarly, one paper listed in $2011^{1}$ was concerned with contact lens-induced papillary conjunctivitis. This condition was observed in patients wearing some $20^{\text {th }}$ century reusable hydrogel lenses, but is far less prevalent today ${ }^{20}$ because of the ubiquity of disposable lenses; ${ }^{18}$ accordingly, there are no papers concerning papillary conjunctivitis in the current listing.

Although silicone hydrogel lenses have solved hypoxic problems, they have not reduced the incidence of keratitis, which remains an issue of concern. There were five papers addressing this problem in the 2011 listing, ${ }^{1}$ and there are four in the current listing in Table 1 , in relation to epidemiology ${ }^{9,10}$ (those papers ranked $\# 2$ and \#3), bacterial lens contamination ${ }^{11}(\# 4)$ and risk factors for keratitis ${ }^{15}(\# 8)$.

Other papers in the current listing reflect topics of emerging interest in the field, including two papers on the use of orthokeratology to arrest the progression of myopia, ${ }^{12,13}$ both by Cho and co-workers (\#5 and \#6), and two papers describing smart electronics incorporated into contact lenses for wireless biological sensing ${ }^{14,17}$ (\#7 and \#10). Contact lens discomfort remains an intractable problem, with the paper by Nichols and Sinnott ${ }^{16}(\# 9)$ reflecting this concern. 


\section{Impactful authors}

Eight esteemed colleagues who appeared in the 2011 listing $^{1}$ have been displaced by a new generation of contact lens researchers, as listed in Table 2. Mark Willcox (rank \#2) and Nathan Efron (\#4) still appear high in the rankings, as they were in 2011 (then ranked \#2 and \#3, respectively). Fiona Stapleton (\#3), Brien Holden (\#8) and Dwight Cavanagh (\#10) are the other names remaining from the 2011 listing.

A new name appears at the top of the current ranking - Lyndon Jones. He is a prolific author, who has also published the highest number of contact lens-related papers by a wide margin from the second most prolific author, Nathan Efron. Professor Jones heads the Centre for Ocular Research \& Education (CORE) - a large and active group that undertakes contractual research and consulting for the contact lens industry, as well as undertaking independent fundamental contact lens and solutions research.

Other new names in Table 2 include Philip Morgan (\#5), Anuj Chauhan (\#6), Pauline Cho (\#7) and Jason Nichols (\#9). Professors Chauhan and Nichols only entered academia and commenced publishing around the turn of the century, which is essentially the beginning of this survey period; their listing in the top 10 is therefore a remarkable achievement.

It is noteworthy that seven of the top 10 authors are optometrists; Mark Willcox (\#2) is a microbiologist, Anuj Chauhan (\#6) an engineer and Dwight Cavanagh (\#10) an ophthalmologist. This observation attest to the leading professional standing of optometry in the contact lens literature.

\section{Top institutions}

All nine universities listed in Table 3 are essentially the parent institutions to optometry departments. The University of New South Wales (basically the School of Optometry and Vision Science) and the Brien Holden Vision Institute - although housed in the same building on the same university campus in Sydney, Australia are distinct organisational entities and are therefore listed separately. As was the case in $2011,{ }^{1}$ these two institutions remain highly ranked in the present listing, at \#1 and \#3, respectively. The University of Waterloo, Canada (\#2) and University of Manchester, United Kingdom (\#4) are home to internationally-acclaimed contact lens research facilities - CORE, as noted earlier, headed by Lyndon Jones (rank \#1 in Table 2), and Eurolens Research, headed by Philip Morgan (\#5), respectively.

The 2011 top 10 listing $^{1}$ only contained institutions from Australia, Canada, the United Kingdom and the United States. Institutions from three additional countries appear in the current listing - The University of Minho (Portugal) (\#7), Hong Kong Polytechnic University (Hong Kong) (\#8) and the University of Valencia (Spain) (\#10) - signalling the emergence of these three institutions as internationally-recognised centres of 
excellence for contact lens research. The Queensland University of Technology (Australia) (\#6) is another new entrant to the listing, built upon a broad foundation of research into lens design, optics, anterior eye physiology, advanced ophthalmic imaging and myopia control. The Ohio State University (\#5), which was one of five United States-based institutions featured in the 2011 listing, ${ }^{1}$ is now the only United States school among the top 10 institutions.

\section{Leading countries}

There has only been a slight redistribution of rankings among the top eight countries included in Table 4 compared to the 2011 listing. ${ }^{1}$ However, two countries that were ranked \#8 and \#9 in 2011 - France and The Netherlands - have been displaced by Portugal and Turkey at ranks \#9 and \#10, respectively. That the United States is producing the most impactful contact lens papers as well as the highest number of papers is unsurprising in view of the large number of optometry schools in that country, many of which are located in high-ranking research-led institutions. As well, the headquarters of many of the major contact lens and solution companies are housed in the United States, facilitating more immediate interaction between these companies and university research departments, at many levels. Australia (\#2) continues to perform disproportionately well in relation to its relatively small population size.

\section{Prominent journals}

The most impactful journals publishing contact lens-related papers are presented in Table 5. The journals Eye and Contact Lens and Contact Lens and Anterior Eye primarily publish papers relating to contact lenses, as indicated by their titles, so is is not surprising that they rank \#1 and \#2, respectively, in terms of paper counts. However, they are not the most impactful journals, and are ranked $\# 3$ and $\# 4$ by $\mathrm{h}_{\mathrm{CL}}-20$-index, respectively. These two journals only commenced publishing in the 1970s, compared with some of the more established journals listed in Table 5, which have been in existence for over a century. This partly explains why Eye and Contact Lens and Contact Lens and Anterior Eye did not feature in the top 10 journals by paper count in the 2011 listing, ${ }^{1}$ which considered contact lens papers published over the previous 110 years.

There are currently four major optometry journals in the world, and all appear in this top 10 ranking list Optometry and Vision Science (United States) (\#1), Ophthalmic and Physiological Optics (United Kingdom) (\#6), Clinical and Experimental Optometry (Australia) (\#7), and Journal of Optometry (Spain) (\# 10). Table 2 lists only two journals with "ophthalmology" in their titles - Investigative Ophthalmology and Visual Science and American Journal of Ophthalmology, ranked \#2 and \#8, respectively. 


\section{Conclusions}

This contemporary examination of the contact lens literature reveals a heightened interest in topics such as orthokeratology for myopia control and wireless biosensing contact lenses. There is also a notable 'changing of the guard' in terms of individual researchers, with Lyndon Jones heading the table as the most impactful author of contact lens-related papers. Two new countries (Portugal and Turkey) and five new institutions appear in the top 10 listings.

Although the two dedicated contact lens journals - Contact Lens and Anterior Eye and Eye and Contact Lens are, unsurprisingly, custodians of the greatest number of contact lens-related papers published in the $21^{\text {st }}$ century, they are not the most impactful journals in the contact lens field. The journals Optometry and Vision Science (\#1) and Investigative Ophthalmology and Visual Science (\#2) have the highest $\mathrm{h}_{\mathrm{CL}}$-indices and are thus deemed to have the highest impact of all journals publishing papers relating to contact lenses.

A proclamation of the lead author of this work (NE) in 2010, made without any real evidence at the time, was that "Of all the fields of clinical activity in which optometrists are engaged, contact lens research is perhaps the only field of which optometry can claim true ownership." 21 The current analysis confirms this notion, as evidenced by the dominance of optometric authors, and institutions housing optometry departments, in these top 10 rankings.

The lead author (NE) also wrote in 2015: “ ... it is likely that ... [the Spanish publication Journal of Optometry] ... and Spanish authors and institutions will hold prominent positions in international ranking tables if ... citation analyses are repeated in the next few years." 22 The present analysis demonstrates that this prediction has been realised, and it is gratifying to see the tremendous advances that our Iberian colleagues have made in the contact lens field this century.

\section{REFERENCES}

1. Efron N, Brennan NA, Nichols JJ. Citation analysis of the contact lens field. Optom Vis Sci 2012; 89: 70-79.

2. Cardona G, Sanz JP. Citation parameters of contact lens-related articles published in the ophthalmic literature. Eye Contact Lens 2014; 40: 301-304.

3. Cardona G, Sanz JP. Publication analysis of the contact lens field: what are the current topics of interest? J Optom 2015; 8: 33-39.

4. Dutta D, Woods CA. Reflection of contact lens practice. Cont Lens Anterior Eye 2019; 42: 587-589.

5. Alvarez-Peregrina C, Sanchez-Tena MA, Martin M, et al. Multifocal contact lenses: A bibliometric study. J Optom. doi: 10.1016/j.optom.2020.07.007. 
6. Villa-Collar C, Alvarez-Peregrina C, Hidalgo Santa Cruz F, et al. Bibliometric study of scientific research on overnight orthokeratology. Eye Contact Lens 2018; 44: 344-349.

7. Nichols JJ, Jones LW, Morgan PB, et al. Bibliometric analysis of the orthokeratology literature. Cont Lens Anterior Eye (in press).

8. Nicolson PC, Vogt J. Soft contact lens polymers: An evolution. Biomaterials 2001; 22: 3273-3283.

9. Chang DC, Grant GB, O'Donnell K, et al. Multistate outbreak of Fusarium keratitis associated with use of a contact lens solution. JAMA 2006; 296: 953-963.

10. Stapleton F, Keay L, Edwards K. the incidence of contact lens-related microbial keratitis in Australia. Ophthalmology 2008; 115: 1655-1663.

11. Bruinsma GM, Van Der Mei HC, Busscher HJ. Bacterial adhesion to surface hydrophilic and hydrophobic contact lenses. Biomaterials 2001; 22: 3217-3224.

12. Cho P, Cheung SW, Edwards M. The longitudinal orthokeratology research in children (LORIC) in Hong Kong: A pilot study on refractive changes and myopic control. Curr Eye Res 2005; 30: 70777085.

13. Cho P, Cheung SW. Retardation of myopia in orthokeratology (ROMIO) study: A 2-year randomized clinical trial. Invest Ophthalmol Vis Sci 2006; 47: 1319-1328.

14. Kim J, Kim M, Lee M-S. Wearable smart sensor systems integrated on soft contact lenses for wireless ocular diagnostics. Nat Commun 2017; 8(14997): doi: 10.1038/ncomms14997.

15. Dart JKG, Radford CF, Minassian D, et al. Risk factors for microbial keratitis with contemporary contact lenses. A case-control study. Ophthalmology 2008; 115: 1647-1654.

16. Nichols JJ, Sinnott LT. Tear film, contact lens, and patient-related factors associated with contact lensrelated dry eye. Invest Ophthalmol Vis Sci 2006; 47: 1319-1328.

17. Liao Y-T, Yao H, Lingley A, et al. A 3- $\mu \mathrm{W}$ CMOS glucose sensor for wireless contact-lens tear glucose monitoring. IEEE J Solid-State Circuits 2012; 47: 335-344.

18. Morgan PB, Woods CA, Tranoudis IG, et al. International contact lens prescribing in 2019. Contact Lens Spectrum 2020; 35(1): 26-31.

19. Covey M, Sweeney DF, Terry R et al. Hypoxic effects on the anterior eye of high-Dk soft contact lens wearers are negligible. Optom Vis Sci 2001; 78: 95-99.

20. Cho P, Boost MV. Daily disposable lenses: the better alternative. Cont Lens Anterior Eye 2013; 36: 412.

21. Efron N. A 50th anniversary celebration. Clin Exp Optom 2010; 93: 1-2.

22. Efron N. Contact lens citation metrics - The Spanish connection. J Optom 2015; 8: 1. 
Table 1 . Top 10 most cited contact lens articles published in the $21^{\text {st }}$ century, ranked by citation count

\begin{tabular}{|c|c|c|c|c|c|}
\hline Rank & Title & First Author & Journal & Year & Citations \\
\hline 1 & Soft contact lens polymers: An evolution ${ }^{8}$ & Nicolson PC & Biomaterials & 2001 & 484 \\
\hline 2 & $\begin{array}{l}\text { Multistate outbreak of Fusarium keratitis } \\
\text { associated with use of a contact lens } \\
\text { solution }^{9}\end{array}$ & Chang DC & $\begin{array}{l}\text { Journal of the } \\
\text { American Medical } \\
\text { Association }\end{array}$ & 2006 & 407 \\
\hline 3 & $\begin{array}{l}\text { The incidence of contact lens-related } \\
\text { microbial keratitis in Australia }{ }^{10}\end{array}$ & Stapleton F & Ophthalmology & 2008 & 353 \\
\hline 4 & $\begin{array}{l}\text { Bacterial adhesion to surface hydrophilic } \\
\text { and hydrophobic contact lenses } \\
11\end{array}$ & Bruinsma GM & Biomaterials & 2001 & 306 \\
\hline 5 & $\begin{array}{l}\text { The longitudinal orthokeratology research } \\
\text { in children (LORIC) in Hong Kong: A } \\
\text { pilot study on refractive changes and } \\
\text { myopic control }{ }^{12}\end{array}$ & Cho P & $\begin{array}{l}\text { Current Eye } \\
\text { Research }\end{array}$ & 2005 & 300 \\
\hline 6 & $\begin{array}{l}\text { Retardation of myopia in orthokeratology } \\
\text { (ROMIO) study: A } 2 \text {-year randomized } \\
{\text { clinical trial }{ }^{13}}\end{array}$ & Cho P & $\begin{array}{l}\text { Investigative } \\
\text { Ophthalmology } \\
\text { and Visual Science }\end{array}$ & 2012 & 269 \\
\hline 7 & $\begin{array}{l}\text { Wearable smart sensor systems integrated } \\
\text { on soft contact lenses for wireless ocular } \\
\text { diagnostics }^{14}\end{array}$ & Kim J & $\begin{array}{l}\text { Nature } \\
\text { Communications }\end{array}$ & 2017 & 239 \\
\hline 8 & $\begin{array}{l}\text { Risk factors for microbial keratitis with } \\
\text { contemporary contact lenses. A case- } \\
\text { control study }{ }^{15}\end{array}$ & Dart JKG & Ophthalmology & 2008 & 228 \\
\hline 9 & $\begin{array}{l}\text { Tear film, contact lens, and patient-related } \\
\text { factors associated with contact lens-related } \\
\text { dry eye }{ }^{16}\end{array}$ & Nichols JJ & $\begin{array}{l}\text { Investigative } \\
\text { Ophthalmology \& } \\
\text { Visual Science }\end{array}$ & 2006 & 225 \\
\hline 10 & $\begin{array}{l}\text { A 3- } \mu \mathrm{W} \text { CMOS glucose sensor for } \\
\text { wireless contact-lens tear glucose } \\
\text { monitoring }{ }^{17}\end{array}$ & Liao Y-T & $\begin{array}{l}\text { IEEE Journal of } \\
\text { Solid-State Circuits }\end{array}$ & 2012 & 215 \\
\hline
\end{tabular}


Table 2. Top 10 authors of contact lens articles published in the $21^{\text {st }}$ century, ranked by author $\mathrm{h}_{\mathrm{CL}}-20$-index.

4
5
6
7
8
9
10

\begin{tabular}{|c|l|c|c|c|}
\hline Rank & \multicolumn{1}{|c|}{ Author } & $\begin{array}{c}\mathbf{h}_{\mathbf{C L}} \mathbf{- 2 0}- \\
\text { index }\end{array}$ & $\begin{array}{c}\text { Paper } \\
\text { count }\end{array}$ & $\begin{array}{c}\text { Rank in } \\
\mathbf{2 0 1 1}^{1}\end{array}$ \\
\hline 1 & Lyndon Jones & 32 & 140 & NR \\
\hline 2 & Mark Willcox & 31 & 102 & 2 \\
\hline 3 & Fiona Stapleton & 30 & 88 & 8 \\
\hline 4 & Nathan Efron & 29 & 103 & 3 \\
\hline 5 & Philip Morgan & 26 & 91 & NR \\
\hline 6 & Anuj Chauhan & 24 & 49 & NR \\
\hline 7 & Pauline Cho & 23 & 84 & NR \\
\hline 8 & Brien Holden & 23 & 50 & 1 \\
\hline 9 & Jason Nichols & 21 & 58 & NR \\
\hline 10 & Dwight Cavanagh & 21 & 37 & 10 \\
\hline
\end{tabular}

$\mathrm{NR}=$ not ranked 
Table 3. Top 10 institutions from where contact lens articles were published in the $21^{\text {st }}$ century, ranked by institution $\mathrm{h}_{\mathrm{CL}}-20$-index.

\begin{tabular}{|c|l|c|c|c|c|}
\hline Rank & \multicolumn{1}{|c|}{ Institution } & Country & $\begin{array}{c}\mathbf{h}_{\text {CL-20- }} \text { index } \\
\text { inaper } \\
\text { count }\end{array}$ & $\begin{array}{c}\text { Rank in } \\
\mathbf{2 0 1 1}^{1}\end{array}$ \\
\hline 1 & University of New South Wales & Australia & 48 & 305 & $1^{\text {a }}$ \\
\hline 2 & University of Waterloo & Canada & 39 & 191 & 6 \\
\hline 3 & Brien Holden Vision Institute & Australia & 39 & $175^{\mathrm{b}}$ & $\mathrm{NR}^{\mathrm{a}}$ \\
\hline 4 & University of Manchester & United Kingdom & 33 & 147 & 10 \\
\hline 5 & The Ohio State University & United States & 31 & 119 & 5 \\
\hline 6 & Queensland University of Technology & Australia & 24 & 114 & $\mathrm{NR}$ \\
\hline 7 & University of Minho & Portugal & 23 & 100 & $\mathrm{NR}$ \\
\hline 8 & Hong Kong Polytechnic University & Hong Kong & 23 & 96 & $\mathrm{NR}$ \\
\hline 9 & Aston University & United Kingdom & 21 & 87 & NR \\
\hline 10 & University of Valencia & Spain & 17 & 81 & NR \\
\hline
\end{tabular}

$\mathrm{NR}=$ not ranked.

a. in the 2011 listing, counts for the Brien Holden Vision Institute and the Co-operative Research Centre for Eye Research and Technology were combined into a single count together with, and listed as, the University of New South Wales.

b. count includes papers attributed to the Co-operative Research Centre for Eye Research and Technology. 
Table 4. Top 10 countries from where contact lens articles were published in the $21^{\text {st }}$ century, ranked by country $\mathrm{h}_{\mathrm{CL}}$-20-index.

\begin{tabular}{|c|c|c|c|c|}
\hline Rank & Country & $\begin{array}{c}\mathbf{h}_{\mathrm{CL}^{-}-20-} \\
\text { index }\end{array}$ & $\begin{array}{l}\text { Paper } \\
\text { count }\end{array}$ & $\begin{array}{c}\text { Rank in } \\
2^{2011^{1}}\end{array}$ \\
\hline 1 & United States & 79 & 1,229 & 1 \\
\hline 2 & Australia & 56 & 499 & 2 \\
\hline 3 & United Kingdom & 52 & 524 & $3^{\mathrm{a}}$ \\
\hline 4 & Canada & 39 & 284 & 4 \\
\hline 5 & Spain & 37 & 356 & 6 \\
\hline 6 & Japan & 34 & 239 & 5 \\
\hline 7 & China & 30 & 267 & 7 \\
\hline 8 & India & 26 & 148 & 10 \\
\hline 9 & Portugal & 26 & 127 & NR \\
\hline 10 & Turkey & 18 & 131 & NR \\
\hline
\end{tabular}

a. the 2011 ranking related to England only, and did not count papers from the rest of the UK. $\mathrm{NR}=$ not ranked. 
Table 5. Top 10 journals publishing contact lens articles in the $21^{\text {st }}$ century, ranked journal $\mathrm{h}_{\mathrm{CL}}-20$-index.

\begin{tabular}{|c|l|c|c|c|}
\hline Rank & \multicolumn{1}{|c|}{ Journal } & $\begin{array}{c}\mathbf{h}_{\mathbf{C L}}-\mathbf{2 0}- \\
\text { index }\end{array}$ & $\begin{array}{c}\text { Paper } \\
\text { count }\end{array}$ & $\begin{array}{c}\text { Rank in } \\
\mathbf{2 0 1 1}^{1}\end{array}$ \\
\hline 1 & Optometry and Vision Science & 49 & 377 & 1 \\
\hline 2 & Investigative Ophthalmology and Visual Science & 46 & 143 & 6 \\
\hline 3 & Eye and Contact Lens & 40 & 602 & NR \\
\hline 4 & Contact Lens and Anterior Eye & 38 & 525 & NR \\
\hline 5 & Cornea & 34 & 153 & 5 \\
\hline 6 & Ophthalmic and Physiological Optics & 25 & 84 & 10 \\
\hline 7 & Clinical and Experimental Optometry & 24 & 139 & NR \\
\hline 8 & American Journal of Ophthalmology & 22 & 46 & 2 \\
\hline 9 & Current Eye Research & 19 & 72 & 9 \\
\hline 10 & Journal of Optometry & 11 & 46 & NR \\
\hline
\end{tabular}

$\mathrm{NR}=$ not ranked 